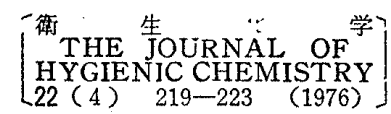

レニウムとジメチルグリオキシムを用いる水中の硝酸イオンの吸光光度定量

\author{
平古場 朗, 永淵 修 \\ 福岡県流域下水道那珂管理事務所, 水処理研究室 ${ }^{11}$
}

\title{
Spectrophotometric Determination of Nitrate Ion in Water using Rhenium and Dimethylglyoxime
}

\author{
Akira Hirakoba and Osamu Nagafuchi \\ Fukuoka Prefectural Naka Sewage Treatment Center, \\ Water Research Laboratory ${ }^{13}$
}

(Received December 12, 1975)

\begin{abstract}
Nitrate ion quantitatively interferes in the complexation of rhenium and dimethylglyoxime in the presence of stannous chloride. Therefor, this reaction can be used for the determination of nitrate ion. This method was applicable to the determination of nitrate-nitrogen in the range of $0.1-3.5 \mathrm{ppm}$. The standard deviation was $\pm 3.0 \%$ on an average absorbance of the $2.0 \mathrm{ppm}$ nitrate-nitrogen solution. Many coexisting substances except copper (II) did not interfere in the determination of nitrate ion. The procedure is as follows: A sample solution $(10 \mathrm{ml})$ containing less than $35 \mu \mathrm{g}$ of nitrate-nitrogen is placed in a $50-\mathrm{ml}$ volumetric flask, $1 \mathrm{ml}$ of $35 \%$ hydrochloric acid, $15 \mathrm{ml}$ of $99.5 \%$ ethanol, $3 \mathrm{ml}$ of $200-\mathrm{ppm}$ rhenium solution, and $4 \mathrm{ml}$ of stannous chloride solution are added, and the mixture is allowed to stand for $25 \mathrm{~min}$ after shaking. To this mixture, $6 \mathrm{ml}$ of $1 \%$ dimethylglyoxime solution is added, and the whole is brought to $50 \mathrm{ml}$ with water. The absorbance of the developed color is measured at $442 \mathrm{~nm}$ after about $25 \mathrm{~min}$.
\end{abstract}

\section{1. 緒訔}

硝酸イオンの吸光光度定量にはブルシンやフェノール ジスルホン酸を用いる方法2 や還元ジアゾ化法3などが 広く用いられている.これらの方法は検出感度に括いて 優れてはいるが，亜硝酸イオンが妨害するため，共存す る場合にはあらかじめこれを除去しておく必要があり， 操作も煩雑で分析に長時間を要するなどの欠点がある. 下水処理水やし尿処理水のような亜硝酸イオンが共存 し，かなり高濃度の硝酸イオンを含有する試料などにつ いては検出感度が劣っても，西硝酸イオンの妨害がな く，操作が䌪便である分析方法が望ましい. Meloche
$ら^{4)}$ 队 Bloomfield ら5) が報告したレニウムと $\alpha$ ーフリル ジオキシムを用いる間接定量法は, 亜硝酸イオンの妨害 が少なく, 操作も簡便であるが, 呈色が安定せず, 吸光 度の湘定時間を悠密に一定としなければならない。

著者らは，レニウムとジメチルグリオキシムとを用い た硝酸イオンの間接定量法について検討したところ, Bloomfield $5^{5)}$ の方法に比べて検出感度が約 3 倍向上 し, 操作時の時間的制約も緩和される良好な結果が得ら れたので報告する。

\section{2. 試薬および装置}

2. 1 試薬硝酸イオン標準液—1 $105-110^{\circ}$ で乾

1) Location: Nakahisahira, Hakata-ku,Fukuoka (福岡市博多区那珂久平).

2）日本下水道協会，“下水試験方法，”1974年版，日本下水道協会，東京，1974，pp. 127-130.

3）加藤多喜雄, 沖中 裕, 堺 敬一, 分析化学, 3, 231 (1954)； J.L. Lambert, F. Zitomer, Anal. Chem., 32, 1682 (1960); 由比顕之介, 衛生化学, 9, 131 (1963); 森本昌宏, 平古場朗, 石橋龍吾, 分析化学, 12, 1336 (1967).

4) V.W. Meloche, R.L. Martin, W.H. Webb, Anal. Chem., 29, 527 (1957).

5) R.A. Bloomfield, J.C. Guyon, R. Kent Murmann, Anal. Chem., 37, 248 (1965). 
蜗した硝酸カリウム $0.7218 \mathrm{~g}$ を水に溶かして 1 liter し，その $100 \mathrm{ml}$ に水を加克て 1 liter とした。本液 $1 \mathrm{ml}$ は硝酸性空素 $0.01 \mathrm{mg}$ を含む。使用のつぞ本液を適当 な浱度に水で希釈して用いた。

レニウム溶液一一酸化レニウム $\left(\mathrm{Re}_{2} \mathrm{O}_{7}\right) 0.6504 \mathrm{~g}$ を 水に溶かして 1 liter とし，その $40 \mathrm{ml}$ をとり，1/100 N 水酸化ナトリウム夜で中和した後，水を加兄て全量を $100 \mathrm{ml}$ とした。本液 $1 \mathrm{ml}$ はレニウム $0.20 \mathrm{mg}$ を含む。

$25 \%$ 塩化第一スズ容液——塩化第一スズ $25 \mathrm{~g}$ を塩酸 （35\%） $25 \mathrm{ml}$ 飞溶かし，水を加えて $100 \mathrm{ml}$ とした。

$1 \%$ ※゙ィルグリオキシム溶液—ジメチルグリオキ シム $1 \mathrm{~g}$ をチルアルコール $(99.5 \%) 100 \mathrm{ml}$ 飞溶か して用いた。

その活か，㙁酸 (35\%)，エチルフルコール(99.5\%) なぞ，本害験汇用いた試薬は，すべて市販の特級品で ある。

2. 2 装置 光電分光 光度計一一本 分光 製

UVIDEC-1 型光電分光光度計 $\mathrm{pH}$ 計一日立・堀場慗 $\mathrm{M}-7$ 型 $\mathrm{pH}$ 計

\section{3. 定量 法}

3. 1 定量操作 容量 $50 \mathrm{ml}$ のメスフラスコに試料 溶液（硝酸性䆓素として $3.0 \mu \mathrm{g} / \mathrm{ml}$ 以下を含む）を $10 \mathrm{ml}$ とり、これに 99.5\%ェチルアルコール15 $\mathrm{ml}, 35 \%$ 塩酸 $1 \mathrm{ml}$, レニウム溶液 $3 \mathrm{ml}$ 抢よび $25 \%$ 塩化第一スズ溶液 $4 \mathrm{ml}$ を加兄て振り混ぜ，25分間放置する。つぎに1\%シ メチルグリオキシム溶液 $6 \mathrm{ml}$ を加えた後,標線まで水を 加克て $50 \mathrm{ml}$ 之する。約 25 分経過後（その一部を $10 \mathrm{~mm}$ のセルにとり，水を対照として $442 \mathrm{~nm}$ の波長で吸光度 を測定する。あらかじめ作成した検量線から試料溶液中 の硝酸イオン濃度を算出する。

\section{2 検量線硝酸イオン標潐液を希釈し, 濃度の} 異なった数種の液汇ついて3.1 の定量操作により検量 線を作成した。

その結果, 硝酸性窒素の濃度が $0.0-3.5 \mathrm{ppm}$ の範因 内で, 吸光度と硝酸性窒素濃度との関係は, つぎの式で 表わされることがわかった。

$Y=0.9229 \operatorname{Exp}^{-0.3927 X}$

$Y:$ 吸光度

$X:$ 硝酸性窒素濃度 $(\mathrm{ppm})$

したがって，片対数グラフを用いれば，検量線はFig.1 飞示すよう飞，硝酸性窒素濃度 $3.5 \mathrm{ppm}$ まで直線で表 わされる。

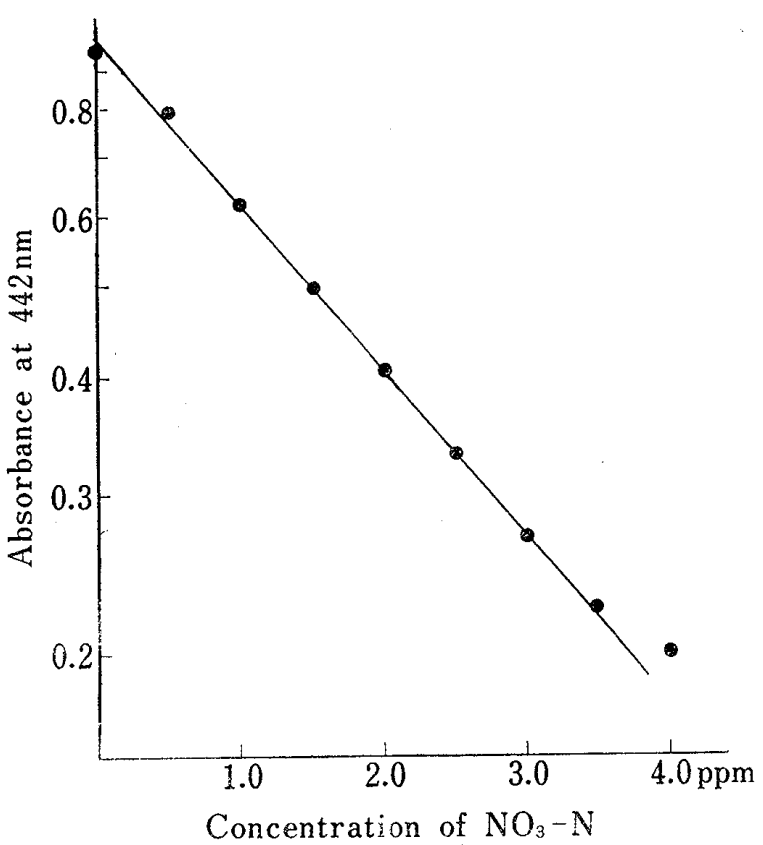

Fig. 1. Calibration Curve

な抢, 硝酸性空素濃度 $2.0 \mathrm{ppm}$ 飞打ける繰り返しの 標準偏盖は $3.0 \%$ であった。

\section{4. 定量条件の検討}

\section{1 吸収曲線}

硝酸イオンを含声溶液 $\left(\mathrm{NO}_{3}-\mathrm{N}\right.$ として $\left.2.0 \mathrm{ppm}\right)$ と含 まない溶液について定量操作を行い，得られた呈色液の 吸収曲線を求めたところ，Fig. 2 とみられるように， いずれの呈色にも $442 \mathrm{~nm}$ 付近に吸収極大があることが 認められた。

布施谷6) はレニウムージメチルグリオキシム錯体の吸 收極大は $462 \mathrm{~nm}$ で，Kenna7) の実験結果より約 $60 \mathrm{~nm}$ 短波長側にあったと報告しているが，著者らの結果によ れば，さらに $20 \mathrm{~nm}$ 短波長側の $442 \mathrm{~nm}$ に吸収極大が認 められた。

\section{2 塩酸添加量}

4. 4 の項で述べる $25 \%$ 塩化第一スズ溶液中に塩酸が 含まれているが，本項に和ける塩酸添加量は2 $25 \%$ 塩化第 一スズ溶液 $4 \mathrm{ml}$ を添加する場合にな打不足となる塩酸 量について検討した，その結果，Fig. 3 飞示すと招り で，塩酸 $(35 \%)$ を $1 \mathrm{ml}$ 添加した場合が最も吸光度が 大きく，添加量がそれ以上になると吸光度は小さくなる 傾向がみられた。

\section{3 アルコール添加量}

メチルアルコールを用いた場合とェチルアルコールを

6）布施谷正義, 分析化学, 13，122（1964）.

7) B.T. Kenna, Anal. Chem., 33, 1130 (1961). 


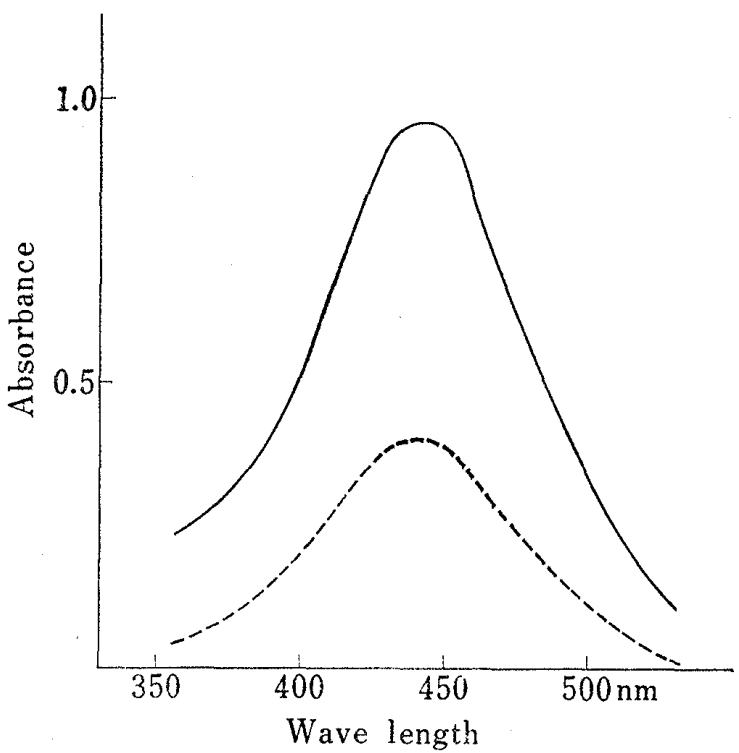

Fig. 2. Absorption Spectrum of the Complex of Rhenium and Dimethylglyoxime - $:$ no added $\mathrm{NO}_{3}-\mathrm{N}$ .... : $20 \mu \mathrm{g}$ of $\mathrm{NO}_{3}-\mathrm{N}$

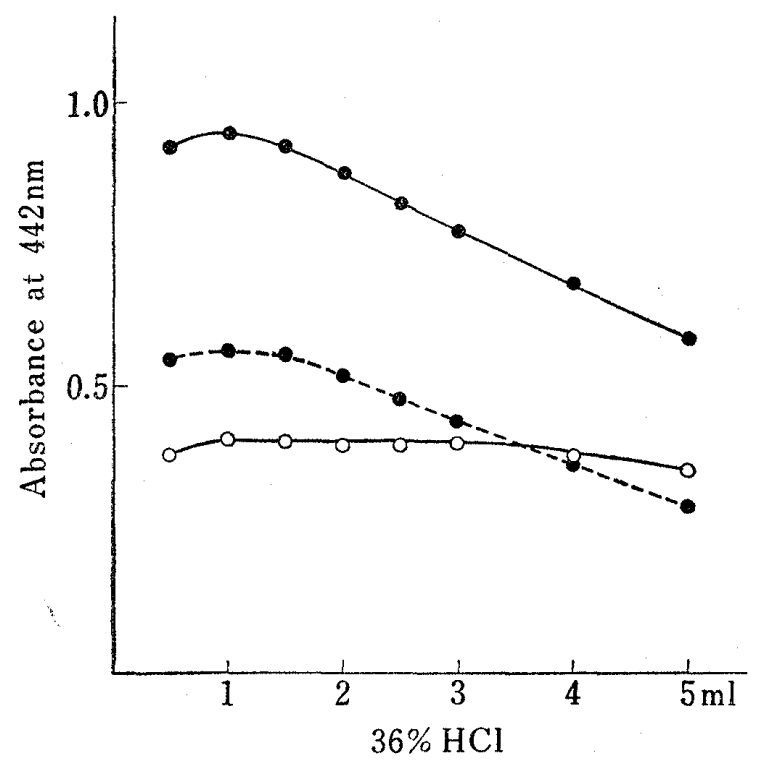

Fig. 3. Effect of Amount of $\mathrm{HCl}$

$$
\begin{aligned}
& -\mathrm{-} \text { : no added } \mathrm{NO}_{3}-\mathrm{N} \\
& -\mathrm{O}-20 \mu \mathrm{g} \text { of } \mathrm{NO}_{3}-\mathrm{N} \\
& \ldots \cdots: \text { difference }
\end{aligned}
$$

用いた場合とに括けるアルコールの添加量が吸光度にお よぼす影響について検討した・ジメチルグリオキシムの 溶解剂として使用するアルコールは，本項で添加するア ルコールと同種類のものを用い，1\%ジメチルグリオキ シム・アルコール溶液の添加量は $6 \mathrm{ml}$ とした。その結 果, Fig. 4 扰よび Fig. 5 に示すようにメチルアルコー ルを用いる場合は $12 \mathrm{ml}$ を，エチルアルコールを用いる

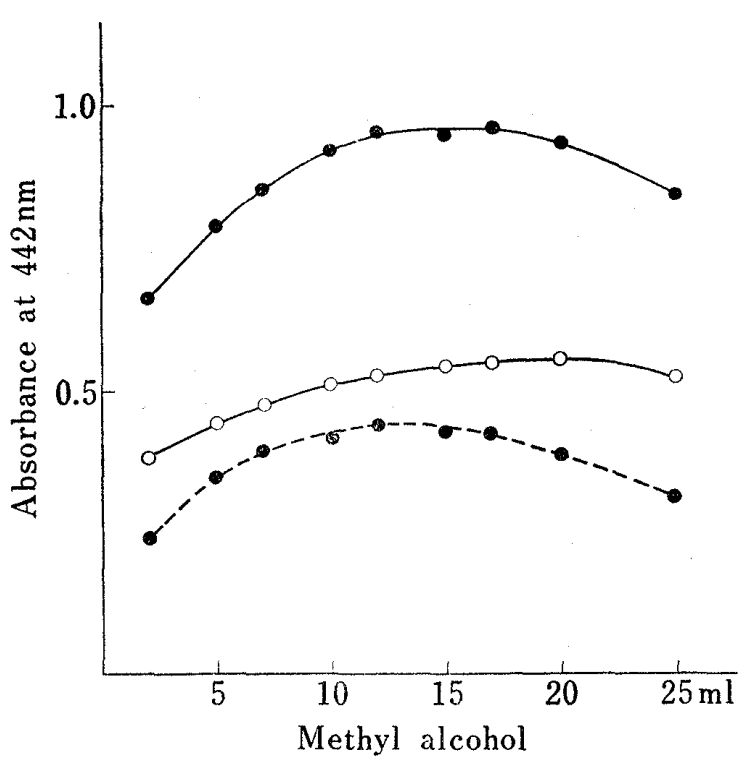

Fig. 4. Effect of Amount of Methyl Alcohol

- - : no added $\mathrm{NO}_{3}-\mathrm{N}$ $-\mathrm{O}-: 20 \mu \mathrm{g}$ of $\mathrm{NO}_{3}-\mathrm{N}$ ...... : difference

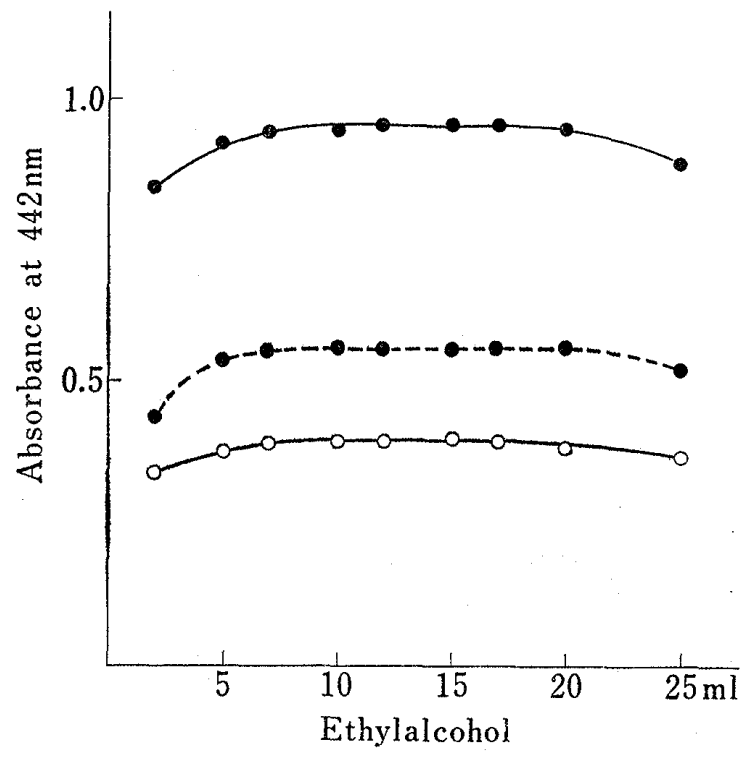

Fig. 5. Effect of Amount of Ethylalcohol

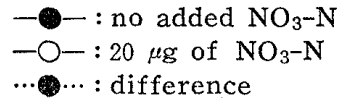

場合は $15 \mathrm{ml}$ を添加するのが最も硝酸イオンの検出感度 が大きく，またエチルアルコールを用いた方が硝酸イオ ンの検出感度がより大きく, 添加量が多少変化しても吸 光度は汪とんぞ一定であることがわかった。したがって 本法ではエチルアルコールを用いることにし，その添加 量は $15 \mathrm{ml}$ とした。

\section{4 塩化第一スズ溶液の添加量}




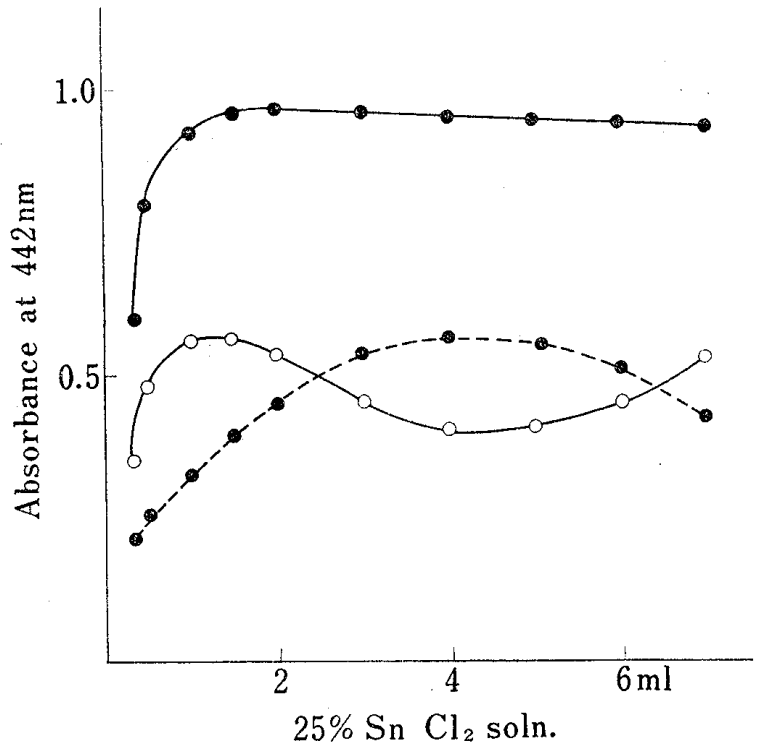

Fig. 6. Effect of Amount of $\mathrm{SnCl}_{2}$ Soln.

$$
\begin{aligned}
& -1-\text { : no added } \mathrm{NO}_{3}-\mathrm{N} \\
& -\mathrm{O}-: 20 \mu \mathrm{g} \text { of } \mathrm{NO}_{3}-\mathrm{N} \\
& \ldots \cdots: \text { difference }
\end{aligned}
$$

25\%塩化第一スズ溶液の添加量について検討した結果 をFig. 6 に示す。これによると，硝酸イオンを含まな い溶液については25\%塩化第一スズ溶液の添加量を增す と $2 \mathrm{ml}$ までは吸光度は大きくなり，それ以上になると 徐々に吸光度は小さくなる傾向がみられ，硝酸イオンを 含む溶液纪いては添加量を増すと $1 \mathrm{ml}$ まで吸光度は 大きくなり，それ以上になると吸光度は減少し， $4 \mathrm{ml}$ 以上になると再び增加する傾向にあった。硝酸イオンの 検出感度が最も大きくなるのは $25 \%$ 塩化第一スズ溶液を 4-5 $\mathrm{ml}$ 添加した場合であったので, 本法では $4 \mathrm{ml}$ 添加することにした。

\section{5 還元剤添加後の放置時間}

$25 \%$ 塩化第一スズ溶液を添加した後, ジメチルグリオ キシムを添加する亲での時間について検討したところ，

Fig. 7 に示すような結果であった。すなわち，硝酸イ オンを含まない場合には, 放置時間が長くなるに従い, 吸光度は徐々泜下し, 硝酸イオンを含む場合には初め 急速に吸光度は低下し，20分以上になると硝酸イオンを 含まない場合と同様な傾向を示した、硝酸イオンの検出 感度が最も大きく，かつ，一定となるのは20分以後であ ったので, 本法では25\%塩化第一スズ溶液を添加し， 25 分経過後, ジメチルグリオキシム溶液を添加することに した.

\section{6 ジメチルグリオキシム添加量と呈色の経時变化} ジメチルグリオキシム試薬の添加量と添加後の呈色の 経時変化について検討したところ, 試薬添加量が多いと

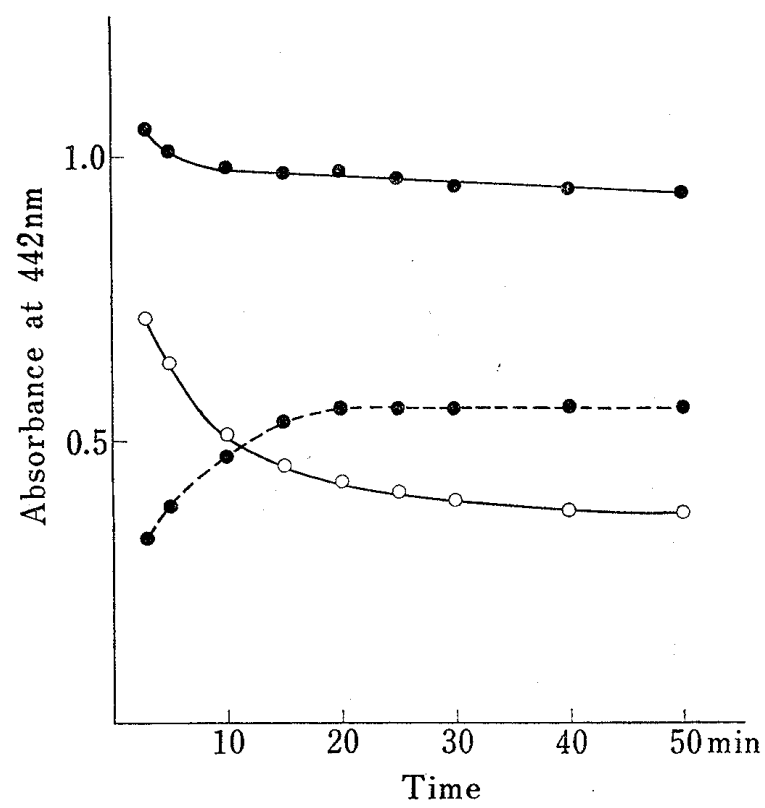

Fig. 7. Influence of Standing Time after Addition of $\mathrm{SnCl}_{2}$ Soln. on the Absorbance
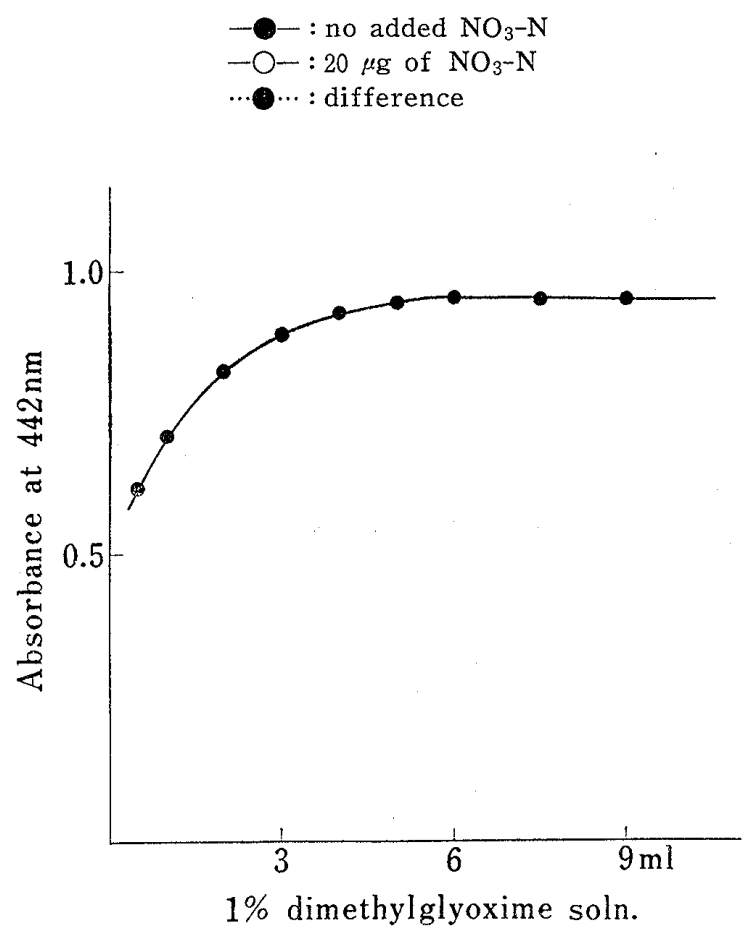

Fig. 8. Effect of Amount of Dimethylglyoxime

発色時間は短いが，その後も徐々に吸光度が增加して一 定さず，添加量が少な過ぎると発色に長時間を要するこ

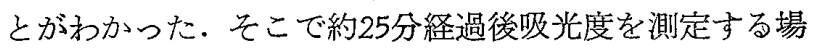
合に最高の発色を示す試薬添加量について検討した．本 実験は硝酸イオンを含まない場合についての及行った。 その結果 Fig. 8 亿示すように，1\%ジメチルグリオキ シム溶液 $5 \mathrm{ml}$ 以上添加すれ惊よいことがわかった。 


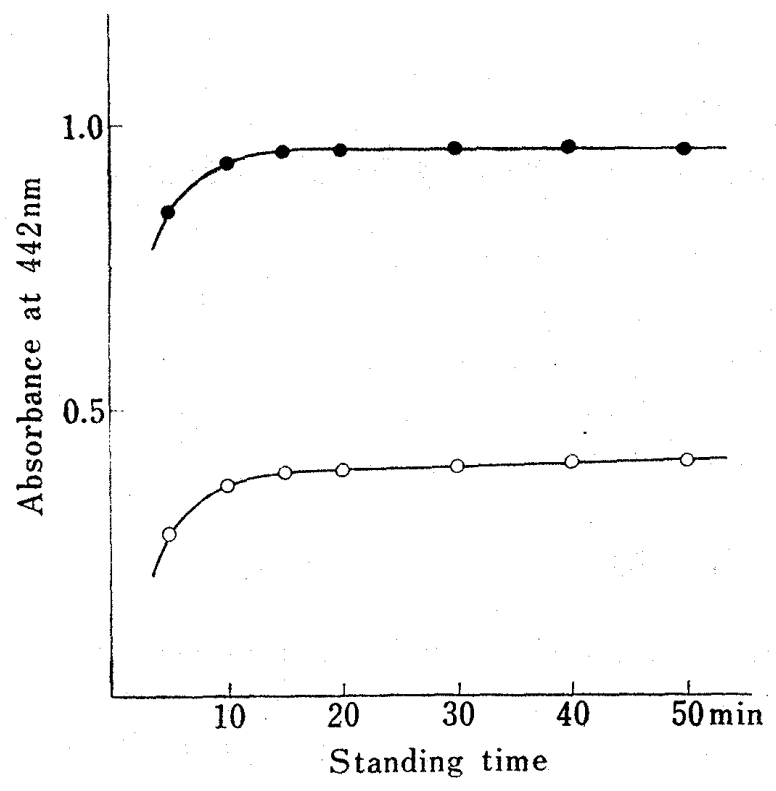

Fig. 9. Effect of Standing Time on the Absorbance

-0 : no added $\mathrm{NO}_{3}-\mathrm{N}$

$-\mathrm{O}-20 \mu \mathrm{g}$ of NO-N

TABLE II. Analytical Results of Nitrate Ion in Sewage Effluents

\begin{tabular}{ccc}
\hline \multirow{2}{*}{ Samples } & \multicolumn{2}{c}{$\mathrm{No}_{3}-\mathrm{N}$ found $(\mathrm{ppm})$} \\
\cline { 2 - 3 } & This method & Brucin method \\
\hline 1 & 0.08 & 0.82 \\
2 & 13.5 & 12.8 \\
3 & 2.25 & 2.24 \\
4 & 15.8 & 15.6 \\
\hline
\end{tabular}

したがって，本法においては $1 \%$ まジメチルグリオキシ ム溶液 $6 \mathrm{ml}$ を添加することにし，その場合の呈色の経 時変化は Fig.9 に示すと扣りであった。すなわち，硝 酸イオンを含まない溶液の場合の吸光度は20分後一定と なり，120 分経過後も汪とんど変化は認められず，硝酸 イオンを含さ溶液の場合の吸光度は時間の経過とともに 若干増加する傾向がみられた。

\section{7 共存イオンの影響}

硝酸性窒素濃度 $2.0 \mathrm{ppm}$ の溶液に各種被検イオンを 添加し，3.1 の定量操作を行った結果を Table I に示 す.これによるとナトリウム，カリウム，カルシウム， マグネシウム，アルミニウム，亜鉛，鉄（II），マンガ ン, 鉛, クロム(VI), コバルト, カドミウム, 水銀(II) アンモニウムの各イオンについては $100 \mathrm{ppm}$ まで存在 しても妨害は認められなかった。亚硝酸, シアン、ニッ ケル，ヒ素，銅の各イオンは多量に存在すれば正または 負の妨害を与えるが，西硝酸イオンについては $80 \mathrm{ppm}$ $\left(\mathrm{NO}_{2}-\mathrm{N}\right.$ とて), ニッケルイオンとシアンイオンにつ
Table I. Effect of Coexisting Substances

\begin{tabular}{|c|c|c|c|}
\hline Substance & $\begin{array}{l}\text { Added } \\
\text { (ppm) }\end{array}$ & $\mathrm{NO}_{3}$ & $\begin{array}{l}-\mathrm{N} \text { found } \\
(\mathrm{ppm})\end{array}$ \\
\hline None & & & 2.00 \\
\hline $\mathrm{Na}$ & 100 & $\mathrm{NaCl}$ & 2.04 \\
\hline $\mathrm{K}$ & 100 & $\mathrm{KH}_{2} \mathrm{PO}_{4}$ & 2.01 \\
\hline $\mathrm{Ca}$ & 100 & $\mathrm{CaCl}_{2}$ & 2.00 \\
\hline $\mathrm{Mg}$ & 100 & $\mathrm{MgSO}_{4} \cdot 7 \mathrm{H}_{2} \mathrm{O}$ & 1.95 \\
\hline $\mathrm{Al}$ & 100 & $\mathrm{Al}_{2}\left(\mathrm{SO}_{4}\right)_{3} \cdot 17 \mathrm{H}_{2} \mathrm{O}$ & 1.96 \\
\hline $\mathrm{Zn}$ & 100 & $\mathrm{Zn}\left(\mathrm{CH}_{3} \mathrm{COO}\right)_{2}$ & 2.01 \\
\hline $\mathrm{Fe}($ III $)$ & 100 & $\mathrm{FeSO}_{4} \cdot 7 \mathrm{H}_{2} \mathrm{O}$ & 2.06 \\
\hline $\mathrm{Mn}$ & 100 & $\mathrm{MnSO}_{4} \cdot 4 \mathrm{H}_{2} \mathrm{O}$ & 2.02 \\
\hline $\mathrm{Pb}$ & 100 & $\mathrm{~Pb}\left(\mathrm{CH}_{3} \mathrm{COO}\right)_{2} \cdot 3 \mathrm{H}_{2} \mathrm{O}$ & 2.02 \\
\hline $\mathrm{Cr}(\mathrm{VI})$ & 100 & $\mathrm{~K}_{2} \mathrm{CrO}_{4}$ & 2.06 \\
\hline Co & 100 & $\mathrm{CoCl}_{2} \cdot 6 \mathrm{H}_{2} \mathrm{O}$ & 2.08 \\
\hline $\mathrm{Cd}$ & 100 & $\mathrm{CdCO}_{3}$ & 1.99 \\
\hline $\mathrm{Hg}(\mathrm{II})$ & 100 & $\mathrm{HgCl}_{2}$ & 1.98 \\
\hline $\mathrm{Ni}$ & 30 & $\mathrm{Ni}\left(\mathrm{NH}_{4}\right)_{2}\left(\mathrm{SO}_{4}\right)_{2} \cdot 6 \mathrm{H}_{2} \mathrm{O}$ & 1.95 \\
\hline As & 10 & $\mathrm{As}_{2} \mathrm{O}_{3}$ & 1.92 \\
\hline $\mathrm{Cu}$ & 1 & $\mathrm{CuSO}_{4} \cdot 5 \mathrm{H}_{2} \mathrm{O}$ & 1.94 \\
\hline $\mathrm{NH}_{3}-\mathrm{N}$ & 100 & $\mathrm{NH}_{4} \mathrm{Cl}$ & 1.96 \\
\hline $\mathrm{NO}_{2}-\mathrm{N}$ & 80 & $\mathrm{NaNO}_{2}$ & 2.02 \\
\hline $\mathrm{CN}$ & 30 & $\mathrm{KCN}$ & 1.98 \\
\hline
\end{tabular}

いては $30 \mathrm{ppm} ，$ ヒ素イオンについては $10 \mathrm{ppm}$ ，銅イオ ンについては $1 \mathrm{ppm}$ 以下であればほとんど影響はなか った。

\section{5. 分 析 例}

3. 1 の操作に従い，福岡県流域下水道御笠川終末処 理場の最終沈でん池流出水中の硝酸イオンの定量を行っ た、その結果，Table II に示すように，同時に行った ブルシン法2゙による分析値とほぼ一致していた。

\section{6. 結語}

硝酸イオンとレニウムとの反応およびレニウムとジメ チルグリオキシムとの反応の最良条件は 4.4 の項の実 験結果などにみられるように，それぞれ異なるすのであ ると考えられるが，定量操作の複維化を避讨るため，著 者らはこれら両反応がある程度同時仙満足できる条件を 求めるための検討を行った。

その結果, レニウムの発色試薬として $\alpha$-フリルジオ キシムを用いる Bloomfield ら5) の方法より，操作特の 時間的制約が著しく緩和され，硝酸イオンの検出感度も 約 3 倍向上した。本法の定量範囲は硝酸性窒素濃度 0.1 から $3.5 \mathrm{ppm}$ までで，共存イオンの影響も少なく，操 作が簡便であるので，下水等の処理施設の処理水や污濁 河川水などの分析に最適であると考える。

謝辞 終りに臨み，本研究について多くの御助言を 賜わった福岡県衛生公害センタ一水贅課長 森本昌宏博 士に深く感謝します。 